Bruno Cavalcante Leitão Santos ${ }^{1}$

Francisco de Assis de França Júnior ${ }^{2}$

Caroline Soares da Silva ${ }^{3}$

\title{
A CRIAÇÃO DO SENSO COMUM PUNITIVO POR INTERMÉDIO DA CRIMINOLOGIA MIDIÁTICA: UMA ANÁLISE DA REALIDADE CONSTRUÍDA A PARTIR DE MATÉRIAS EXIBIDAS NO PLANTÃO
} ALAGOAS

\author{
THE CREATION OF PUNITIVE COMMOM SENSE THROUGH MEDIA CRIMINOL- \\ OGY: AN ANALYSIS OF THE REALITY CONSTRUCTED FROM MATERIALS SHOWN \\ AT THE PLANTÃO ALAGOAS
}

\begin{abstract}
Resumo
O presente estudo tem como objetivo geral discutir a contribuição da criminologia midiática na formação do senso comum punitivo, restringindo o pensamento abstrato de forma a levar o receptor da mensagem a acreditar no que o discurso midiático nos revela, direcionando a política criminal de combate ao crime a certos grupos, por meio da criminalização secundária e formação de bodes expiatórios. Com isso, fez-se necessário analisar os discursos midiáticos, principalmente aqueles aos quais estão mais predispostos a influir no pensamento humano, como é o caso dos programas de plantão policial. Desta feita, teve-se como objeto de análise o programa Plantão Alagoas, que vai ao ar das 11 h30 às 14 hoo, sendo observado os discursos de todas as segundas-feiras do mês de fevereiro de 2020. Destarte, foi realizada uma investigação a partir do método
\end{abstract}

1 Doutor em Direito pela PUCRS. Mestre em Direito Público pela UFAL. Professor de Direito Penal no Centro Universitário CESMAC (Maceió/AL). Líder do Grupo de Pesquisa Sistema penal, democracia e direitos humanos e pesquisador do Grupo Direito, contemporaneidade e transformações sociais junto ao CNPq. Advogado. E-mail: brunoleitao.adv@hotmail.com.

2 Doutorando e Mestre em Direito pela Universidade de Coimbra. Professor no Centro Universitário Cesmac (Maceió/AL). Líder do Grupo de Pesquisa Sistema penal, democracia e direitos humanos e pesquisador do Grupo Direito, contemporaneidade e transformações sociais junto ao CNPq. Advogado. E-mail: fafjunior2016@gmail.com.

3 Graduanda em Direito pelo Centro Universitário Cesmac (Previsão para conclusão em 2022). Membro Associada do Instituto Brasileiro de Ciências Criminais (IBCCRIM). Membro da Liga de Estudos em Ciências Criminais (LIDECCRIM). Foi membro do Grupo de Estudos Avançados - GEA IBCCRIM (20182019). E-mail: carolinnesoareso5@hotmail.com. 
qualitativo do discurso midiático do programa supracitado atrelado aos conhecimentos da criminologia midiática (hipotético-dedutivo e revisão bibliográfica), não se pretendendo esgotar todos os aspectos que abrangem o tema.

Palavras-chave: Criminologia midiática. Senso comum punitivo. Discurso midiático.

\begin{abstract}
Our study aims at discussing the contribution of Media Criminology to the formation of punitive common sense, which restricts the abstract thinking, leading the recipient of the message to believe in the media speech, directing the criminal policy of combating crime against certain groups by secondary criminalization and scapegoating. Hence, we analyzed media speeches, especially those that are more likely to influence human thinking, such as police duty programs. Our object of analysis was the program Plantão Alagoas, aired from 11:30am to $2 \mathrm{pm}$. For this analysis, we watched the program every Monday in February 2020. A qualitative study on the media speech of the aforementioned program linked to the knowledge of Media Criminology (hypothetical-deductive and bibliographic review) was conducted, not intending, however, to exhaust the theme.
\end{abstract}

Keywords: Media criminology. Punitive commom sense. Media speech.

\title{
INTRODUÇÃO
}

A criminologia midiática, desde o século XIX, quando a era da informação se consolidava com a transição do uso de jornais de papel para o uso da televisão, e assim por diante, já era amplamente utilizada. Ao perceber seu poderio, tendo sob seu controle a informação a ser difundida, muitos jornalistas profissionais (apresentadores e repórteres em especial, por suas atuações no formato do "ao vivo", no "aqui e agora"), muitas vezes chancelados pelos proprietários dos meios de comunicação, fizeram o uso da televisão ao seu bel prazer, não transmitindo necessariamente a informação de como de fato ocorreu, haja vista que o foco seria entreter o público a fim de garantir a audiência. Desta feita, o que se chama de criminologia midiática acaba figurando como um processo em que a mídia consolida um discurso que chama a atenção e permite certo controle/influência da dinâmica social em variados aspectos.

Nesse contexto, restou cada vez mais visível como integrantes da mídia atuavam (e atuam) influenciando a percepção de mundo da sociedade, decidindo como merecem ser interpretados os fatos com os quais se têm contato, criando, portanto, certos estereótipos de vitimização, fazendo-se com que o público se sinta estimulado ao aplauso (ou à repulsa) de determinados comportamentos. Fatos, portanto, assim interpretados apenas porque seus interlocutores acham (ou simplesmente decidem) que determinadas medidas (como, por exemplo, a pena de morte), apesar de extremas, valeriam o sacrifício de determinados valores democráticos (como a regra da inviolabilidade da vida, por exemplo), 
tudo em função do alegado alto teor de perigo apresentado por determinados grupos sociais (e por sua alegada incorrigibilidade), geralmente constituídos de pessoas historicamente estigmatizadas por aquela outra parcela da sociedade constituída pelo que se denomina cidadãos de bem (melhor seria de bens).

O tripé, que se constitui a partir da impunidade, do medo e da violência, tem sido recorrentemente utilizado pelos discursos midiáticos, objeto da pesquisa, como forma de política criminal cujo objetivo é incitar a segregação e consequente perseguição do eles (os inimigos) para com os tais cidadãos de bem, valendo-se de um falso direito penal garantista. Não obstante, a severidade do castigo se transforma, de forma progressiva, ao que $\operatorname{Sozzo}(2009$, p. 43) intitula de "receita fundamental" para as estratégias de controle do delito, pleiteando um endurecimento da política criminal, tanto no plano dos discursos como também na prática.

Posto isso, o objeto de observação e análise aqui enfocado será o programa televisivo intitulado Plantão Alagoas, que vai ao ar no período comumente dedicado ao almoço, na transição entre a manhã e a tarde (normalmente das 11h3omin até as 14h), mais especificamente os discursos reverberados pelo apresentador em todas as segundas-feiras do mês de fevereiro de 2020, sobretudo porque esse é o dia em que há notícia acumulada do final de semana, o que permite observar a mensagem midiática elaborada sobre uma quantidade maior de fatos. Analisou-se, portanto, a partir daí, os discursos midiáticos que têm como principal característica o fomento de proposições que induzem ao punitivismo populista, como é caso das famosas frases bandido bom é bandido morto ou só se ensina punindo. Tais jargões deixam claro que o local daquele indivíduo é o de marginalizado e que não parece adiantar tentar mudar o discurso, sobretudo pela pecha promovida também por agentes do próprio Estado.

Porquanto, o presente estudo de abordagem essencialmente qualitativa, com pontuais coletas de dados e revisão bibliográfica, visou discutir criticamente a contribuição da criminologia midiática na formação do senso comum punitivo, restringindo o pensamento abstrato de forma a levar o receptor da mensagem a acreditar no que o discurso midiático pode revelar, direcionando a política criminal de enfrentamento do crime a certos grupos, por meio da criminalização secundária e formação de bodes expiatórios.

A escolha do mencionado programa se deu por ser um dos telejornais mais populares em Alagoas, transmitido no horário de almoço pela TV Ponta Verde, que pertence ao grupo Sistema Opinião de Comunicação, em que muitos que estão em seu horário de descanso se dedicam corriqueiramente a assistir. Ademais, fez-se uso das segundas-feiras do mês de fevereiro de 2020 para análi- 
se dos casos com o fito de observar a linguagem do apresentador e reportar quais tipos de crimes eram mais noticiados e o porquê, o que se desenvolve adiante.

Por conseguinte, na primeira seção foi discutido o modo como se revela a construção dos discursos midiáticos e as consequências deles. Na segunda, explanou-se como o telejornalismo se torna uma referência altamente punitivista, demonstrando por meio de dados, sendo estes materializados com uso de gráficos para maior percepção de ocorrência de supostos crimes. Por último, observou-se como tais discursos influenciam o populismo punitivo, fazendo uso de um direito penal do inimigo para legitimá-los.

\section{A CONSTRUÇÃO DOS DISCURSOS}

Os tempos atuais fazem muitos pensarem ser o mais violento do qual a história já possa ter vivido, pensamento este, fruto de uma política criminal que visa o recrudescimento de uma percepção social punitiva, violenta e acima de tudo segregacionista. Ocorre que tudo isso não passa de um viés político que se legitima através de discursos que incitam a violência, pois em apenas uma reflexão histórica, nota-se que, no Brasil - não sendo necessário ir muito longe -, mais especificamente no Código Penal de 1830, detinha em seu rol normativo a aplicabilidade da pena de morte por enforcamento, ou, como se sabe, na época medieval onde havia penas como o trato da corda e o suplício do fogo. (BRASIL, 2020)

Embora não pareça, a criminologia midiática não é recente, pelo contrário, era utilizada até mesmo quando o meio de comunicação consistia apenas no púlpito e na praça. Desta forma, a construção social da realidade se intensifica com o crescimento dos jornais no século XIX, tendo como característica uma causalidade mágica, descrita por Zaffaroni (2012, p. 304), que inclusive poderia estar presente no que ele chamou de "o silêncio cúmplice", evidenciando o poder que a informação - ou a falta dela - tem sobre o indivíduo.

Não obstante, perceba-se que Zaffaroni (2012, p. 305) observa que a televisão vislumbra tudo aquilo que se pode contrapor à capacidade de pensar, manipulando, assim, a moral do indivíduo que não está preparado para receber o bombardeio de informações trazidas pela televisão.

Que a utilização da mídia é estratégica, não se tem dúvidas, e tal fato se mostra revestido de concretude ao se analisar o comportamento humano diante de certas situações e bem como fazendo uso (desta mesma mídia) a seu benefício, como a estimulação da cultura do medo e as chances de vitimização. Por conseguinte, opera-se conjuntamente com a seletividade penal. 
Com isso, há de se pensar em uma verdadeira facção estatal, pois a política criminal como plataforma de governo tem se mostrado como uma legítima política de extermínio, enraizando-se na mente das pessoas através da falácia de que processo eficiente é aquele que pune, e quanto maior a amplitude do sentimento punitivista, melhores seriam os resultados alcançados pela política criminal adotada pelo Estado, o que, aliás, aproxima-nos do período que antecede o iluminismo. Daí porque indaga-se: pretende a política criminal desse Estado (pós)moderno valer-se mesmo do caldo cultural daquele período, onde certas punições durante o processo de investigação, além da tortura, eram tidas como um meio para se legitimar, mantendo-se o desembaraçado (e desmedido) exercício do poder punitivo?

Nessa altura dos argumentos, é relevante constatar, por exemplo, que Girard (1990, p. 13) pontua que a violência irracional não passa de uma violência não saciada, ${ }^{4}$ sendo esta fruto de um judiciário que não faz o ideal de justiça (que na realidade é de vingança) lograr êxito como na expectativa gerada pela população, que, na generalidade, possui um senso de direitos humanos deturpado, como se tais fossem mecanismos de proteção privilegiada dos intitulados como bandidos. Dessa forma, percebe-se que este entendimento é muito utilizado pela mídia, objetivando internalizar o sentimento de justiça não vingada nas pessoas.

Sobre o discurso midiático, diz Natalino (2007, p. 25):

\begin{abstract}
Argumenta-se aqui que a mídia de massa, e em especial o telejornalismo, sustenta uma difusão seletiva de representações sobre criminalidade, justiça e segurança pública, sendo pólo privilegiado de formação do dito e do não-dito sobre o tema. A "verdade" sobre a criminalidade passa pela tela da TV, e os discursos por ela difundidos através de um idioma público específico constroem novas relações de sentido dentro de um mapa de significados socialmente compartilhado, conformando em grande escala o senso comum e a agenda política.
\end{abstract}

Em outras palavras, seria dizer que a mídia, especialmente a mídia policial, cria a sua própria verdade sobre o seu tema principal, qual seja esta, a de incitar a repressão diante daqueles socialmente estigmatizados.

4 Não obstante, Girard (1990), nesse contexto, tenta esclarecer que a violência, por mais que demonstre ser irracional, existe por muitos motivos, passando a se tornar na realidade algo racional, mas que tais razões nunca devem ser levadas a sério. Uma violência não saciada, por sua vez, na esteira do argumentado pelo mencionado autor, tende, portanto, a buscar uma vítima alternativa. 


\section{A SELETIVIDADE DISCURSIVA}

Diante, portanto, dessa sentida influência midiática, que se consolida na medida em que a informação é construída e repassada mais facilmente com sua migração para o ambiente virtual, prescindindo do papel e da movimentação física para sua disseminação, preleciona Natalino $(2007$, p. 26) a existência de um roteiro imbuído de seletividades, normalmente seguido pelos telejornais, com focos diversos, como, por exemplo, numa seletividade temática, numa seletividade argumentativa e numa seletividade ideológica.

Desta feita, há a necessidade de exibir temas que causem comoção social, constituindo a seletividade temática, que atinjam a moral do indivíduo, fazendo-o questionar sobre a conduta do infrator. Deste modo, o discurso argumentativo é decisivo para a exteriorização do ódio e indignação para com o aparato estatal por não ter criado meios para impedir tal ato ou o fato de não punir mais severamente, construindo os rótulos que recaem ao delinquente, concebendo o papel da seletividade ideológica.

Outrossim, observa-se a crítica feita por Lima (2015, p. 35) acerca do papel da mídia no Complexo do Alemão. ${ }^{5}$

A população assustada aceita soluções drásticas e passa a exigir ações controladoras e cerceadoras de direitos como resposta à informação do perigo iminente de crime. Acolhe-se a militarização da gestão da segurança pública, a substituição do controle democrático por regras de ocupação militar, evoca-se um poder punitivo e coercitivo.

É visível como a mídia atua para com a percepção de mundo da sociedade, decidindo como deve ser pensado, criando estereótipos de vitimização, fazendo as pessoas aplaudirem certos atos incoerentes com o que preconiza o Estado Democrático de Direito apenas porque acreditam que tais medidas, apesar de extremas, são necessárias, haja vista o alto teor de perigo que aquele grupo de pessoas estigmatizadas pode oferecer à sociedade do bem. Em consonância com isso, entende-se que:

A criminologia midiática cria a realidade de um mundo de pessoas decentes, diante de uma massa de criminosos, identificada através de este-

5 Região localizada no estado do Rio de Janeiro, na zona norte do município do Rio de Janeiro, tendo sido popularizada pela grande mídia por conta da presença de faç̧ões criminosas que constantemente rivalizam por conta do comércio ilegal de drogas. 
reótipos, que configuram um eles separado do resto da sociedade, por ser um conjunto de diferentes e maus.[...] Este eles é construído por meio de semelhanças, para qual a televisão é o meio ideal, pois joga com imagens, mostrando alguns dos poucos estereotipados que delinquem e, de imediato, os que não delinquiram ou que só incorrem em infrações menores, mas são parecidos. (ZAFFARONI, 2013, p. 197)

A mídia, portanto, utiliza-se do processo de criminalização secundária de forma indistinta, mordaz e totalmente implacável, selecionando assim, quem deverá ser estigmatizado, contaminando até mesmo aquele que não praticou crime algum.

Outrossim, a criminologia midiática, na esteira do argumentado por Zaffaroni (2012, p. 323), disfarça alguns crimes para enquadrá-los em outros que possam gerar maior repercussão, como é o caso do assassinato do cônjuge transformado em roubo com homicídio ou o roubo do vizinho em questão de segurança. Ou seja, sua conduta consiste em transformar uma ocorrência em algo assustadoramente maior, extraordinário, com grande potencial de chamar a atenção. Há, portanto, por parte dos veículos de comunicação, a construção da imagem de que seriam instrumentos imprescindiveis na vida das pessoas, sobretudo para aquelas que querem evitar uma eventual vitimização. Mesmo diante do baixo teor de instrução, da falta de conteúdo que sirva mesmo como instrutivo da prevenção da criminalidade, tais veículos parecem se colocar como a fórmula definitiva na busca pela perseguida paz social.

Não parece, por outro lado, uma tarefa fácil se lembrar de modo constante que se deve pensar criticamente sobre aquela notícia ser verdadeira e até mesmo procurar outras fontes para confirmá-la, uma vez que os apresentadores de atrações sensacionalistas como estas são devidamente treinados para persuadir o público através da argumentação, enraizando um verdadeiro senso comum punitivo.

Por conseguinte, o medo gerado pelo objeto temível deixa de ser normal para ser um fato patológico ao não levar em conta outras situações temíveis e se concentra naquele único. Dito isto, percebe-se que:

De acordo com esse mecanismo de patologização do medo, me precavenho do roubo e não percebo que em meu próprio lar aumenta a violência; com o pretexto do medo de roubo, ninguém para no sinal da es- 
quina, e, o que é mais grave, por medo de roubo, peço mais vigilância ao Estado e quando me dou conta, os que me vigiam me sequestram. (ZAFFARONI, 2012, p. 319)

Esse trecho evidencia o quanto a mídia é poderosa, moldando na mente o que deve ser temido, ao ponto de ser esquecido que o mundo não gira em torno de um só crime, de um só autor, mas principalmente se faz esquecer dos crimes comuns que acontecem dentro da casa de qualquer um, como a violência doméstica que é tão presente, mas tão invisível. Destarte:

O discurso leigo também está entranhado dessa noção de um criminoso natural, adotando certas concepções de pessoas com instintos ruins ou, como no dito popular, que nasceram tortas - o que demonstra como os saberes dotados de cientificidade, por vezes, reproduzem estereótipos do senso comum, dando-lhes a autoridade da linguagem científica, como já destacado acima. (SANTOS, 2016, p. 4)

A formação do discurso midiático tem como principal característica o fomento de proposições que induzem ao punitivismo populista, como é caso das famosas frases bandido bom é bandido morto ou só se ensina punindo. Ademais, Santos $(2016$, p. 6) tem argumentado no sentido de que práticas policiais abusivas fazem parte do cotidiano do sistema criminal, em especial no Brasil, sendo legitimadas pela mídia, permitindo-se suas continuidades diante da ausência de investigação da conduta desses policiais. Não à toa, ainda na esteira do argumento do mencionado autor, frequentemente é utilizado o termo auto de resistência, que, não raramente, tem servido para legitimar execuções, simulando-se confrontos inexistentes.

Com isso, nota-se a naturalização da morte dessas pessoas que atuam como bodes expiatórios para satisfazer as pulsões sociais (FREUD, 2013), exemplificando como essa política de extermínio age contra as intituladas minorias.

\section{A REFERÊNCIA PUNITIVISTA: UMA ANÁLISE SOBRE O PLANTÃO ALAGOAS}

Como já sinalizado, analisou-se o programa Plantão Alagoas, telejornal transmitido pela TV Ponta Verde no horário em que as pessoas costumam parar (em casa ou mesmo no trabalho) para o almoço. 
Desde 2019 a alta audiência se manifesta de modo estático, conforme pronunciamento do próprio jornal:

De acordo com o resultado do Ibope, a TV Ponta Verde está na vice-liderança em toda a programação do horário do almoço, das $11 \mathrm{~h} 30$ às $14 \mathrm{~h}$. $\mathrm{O}$ horário começa pelo Plantão Alagoas, apresentado por Lauro Lima, e que tem duração de uma hora e 45 minutos. $O$ programa policial, que tem 25 anos de existência, registrou 11 pontos de média. (MAGALHÃES, 2019)

Posto isso, observa-se que a Figura 1 apresenta os seguintes dados:

Figura 1 - Distribuição da cobertura local da emissora

\begin{tabular}{|c|c|c|c|c|}
\hline Alagoas & $\begin{array}{c}\text { Domicílios } \\
\text { com TV 2016 }\end{array}$ & $\begin{array}{c}\text { População } \\
2016\end{array}$ & \%IPC 2016 & $\begin{array}{c}\text { Números } \\
\text { de Municí- } \\
\text { pios }\end{array}$ \\
\hline Total & 948.526 & 3.358 .529 & 1,10266 & 102 \\
\hline Cobertura Total & 828.910 & 2.907 .384 & 0,99479 & 83 \\
\hline $\begin{array}{c}\text { \% Cobertura } \\
\text { Total }\end{array}$ & $87,39 \%$ & $86,57 \%$ & $90,22 \%$ & $81,37 \%$ \\
\hline Total Emissoras & 810.846 & 2.837 .318 & 0,98113 & 80 \\
\hline $\begin{array}{c}\text { \% Cobertura } \\
\text { Emissoras }\end{array}$ & $85,48 \%$ & $84,48 \%$ & $88,98 \%$ & $78,43 \%$ \\
\hline SAT & 18.064 & 70.066 & 0,01366 & 3 \\
\hline$\%$ Coberta SAT & $1,90 \%$ & $2,09 \%$ & $1,24 \%$ & $2,94 \%$ \\
\hline Não Coberto & 119.616 & 451.145 & 0,10787 & 19 \\
\hline$\%$ Não Coberto & $12,61 \%$ & $13,43 \%$ & $9,78 \%$ & $18,63 \%$ \\
\hline
\end{tabular}

Fonte: TV Ponta Verde (2020)

Logo, a tabela acima inserida ${ }^{6}$ demonstra a cobertura que já possuía a TV Ponta Verde desde 2016, presente em 80 de 102 munícipios alagoanos. Através dos dados relatados, observa-se o crescimento do alcance de espectadores desde $o$ ano de 2016. Com isso, analisar-se-ão as matérias do referido programa às segundas-feiras do mês de fevereiro de 2020 (05/02;710/02; 17/02 e 24/02). Ade-

6 Os dados de 2016 se fazem presentes em razão da ausência de atualização, dificuldade em encontrar dados atuais, ou de outras fontes confiáveis. Por isso, tornou-se como ponto de partida os dados de 2016 como estatística de cobertura local.

7 Houve a necessidade de substituir a análise da primeira segunda-feira do mês $(03 / 02)$ para a primeira quarta-feira (05/02), haja vista que o programa só foi ao ar a partir do dia 05 de fevereiro, por motivos desconhecidos. 
mais, serão apresentadas apenas as reportagens com maiores pertinências ao presente estudo.

\section{ANÁLISE DOS DADOS}

No dia 5 de fevereiro de 2020 (PLANTÃO..., 2020a) o programa começa com o seguinte anúncio do apresentador:

Apresentador (AP): Bom dia Maceió, bom dia Alagoas! [...] Houve troca de tiros, foi 'terê-tetê,, três criminosos, três bandidos, três ladrões foram comer capim pela raiz, foram fazer as pazes com o capeta meu 'fio', morreram, morreram!. Seguida da manchete: "Operação termina com três mortos no Pilar".

A segunda manchete do dia é "Adolescente é apreendido 'desfilando' com arma de fogo no Santa Amélia". Dessa vez, é de suma importância relatar parte da entrevista do repórter com o policial que realizou a operação:

Repórter (RE): [...] Agora ele 'tava' andando com ela (a arma) acredito que enrolado em alguma coisa?

Policial (PO): Não, nãa. Ele disse que era 'pra' proteção dele, com medo de ser morto. Talvez esteja sofrendo ameaça. 'Pra' gente ele não contou muita coisa, mas creio que 'pra' autoridade competente ele irá informar.

RE: Mas é muita cara de pau, né? Muita audácia achar que a impunidade existe, até certo ponto a gente acredita que sim, mas quando 'tá' o pessoal da polícia militar nas ruas olhando, patrulhando, o resultado é sempre positivo né. [...] Bom, ele já falou se já 'rodou's alguma vez antes?

PO: Não, ele não informou. Disse que nunca foi preso na realidade.

$R E$ : Vocês foram até a residência dele?

PO: Fomos até a residência, falamos com a mãe, trouxemos 'pra' cá, vamos averiguar.

RE: A mãe falou se era um menino que dá dor de cabeça ou 'pra' ela foi uma surpresa?

PO: Parecia que 'tava' esperando, né? Pessoa de bem, buscando o melhor para o filho, muitas orientações. Mas como as crianças de hoje não querem ouvir o conselho dos pais, o resultado é esse.

$R E$ : $E$, o que os pais não fazem em casa às vezes o Estado, como a Polícia Militar, que é o representante direto, acaba fazendo. Pegando criancinha do mal e trazendo aqui para a Central de Flagrantes. O garoto 'tá' aqui né, ele tem 17 anos, não pode ser identificado, lógico, já não podia né, de acordo com o Estatuto da Criança e do Adolescente, agora é que não pode de jeito nenhum. (Mas) não tem nenhum parágrafo, não tem nenhum inciso que proíba de conversarmos com ele para pelo menos para saber, ouvir se a 'vozinha' dele é suave. [...] Meu querido, essa 'arminha' você comprou 'pra' quê? Você 'tá' sendo ameaçado por alguém? Quem 'tá' ameaçando você? Sua mãe disse

8 Termo informal utilizado para designar se já foi preso. 
que já esperava que a polícia pudesse chegar em casa e encontrar isso. O que vocêtem a falar? Vocêjá 'rodou' antes? Não, né?

O adolescente, por sua vez, não quis se pronunciar para a infelicidade do repórter. Por conseguinte, é a vez do apresentador:

AP: [...] É lamentável, isso mostra o quanto nossas famílias estão fragilizadas. Isso mostra o quanto nós estamos perdendo nossos filhos, sobrinhos, primos mais novos para a criminalidade. Cada vez mais o crime organizado vem 'arrebanhando' seus soldados e infelizmente um dia o seu filho, a sua filha corre o risco de se tornar um desses soldados do crime. Eu não quero que isso aconteça jamais, jamais. [...]

Em outra reportagem, a manchete em destaque é "Ex-reeducando é assassinado com seis tiros", e não poderia faltar a contribuição do apresentador:

AP: Pois é, é aquela velha história, o camarada vivia no mundo do crime, vivia na criminalidade, tinha saído da cadeia, só que não se sabe o que ele andou aprontando antes de ser preso, quando foi preso e até depois de deixar o presídio. É exatamente esse passado de crime que vem em busca da pessoa. (Mas) vem e vem com força, camarada. Se mete com o que não deve, faz o que não deve e uma hora essa conta chega. [...]

Já no dia 10 de fevereiro do mesmo ano (PLANTÃO..., 2020b), o programa se limitou a focar mais em um único caso, onde uma criança tinha sido morta, com indícios de estupro, tendo como principal suspeito uma pessoa da família.

Contudo, no dia 17 do mesmo mês (PLANTÃO..., 2020c), a história se repete, sendo transmitidos vários casos de homicídio ou de crimes patrimoniais. (Mas) algo que chama a atenção de qualquer indivíduo com o mínimo de senso crítico que seja, foi o pronunciamento do apresentador com relação ao caso da manchete "Jovem é preso depois de confessar assassinato de suposto assaltante":

AP: [...] É o tal do justiçamento, a justiça feita com as próprias mãos. [...] Não dá 'pra' fazer esse tipo de justiçamento. [...] Às vezes tem alguém que diz "Mas, rapaz, você diz que é contra esse tipo de justiçamento?" E sou, porque quando acontece, e eu sempre gosto de deixar isso bem claro porque eu sou contra o justiçamento, porque o cidadão de bem passa a ser criminoso quando comete tal justiçamento. Não tem outra. Aos olhos da lei, ele passa a ser um assassino. [...] 
Por conseguinte, no dia 24 de fevereiro (PLANTÃO..., 2020d) o programa teve uma duração menor, com cerca de 60 minutos, ${ }^{9}$ por causa da programação de carnaval. Dentre todo seu percurso, o apresentador se absteve de tecer muitos comentários, com exceção daqueles rotineiros como "espero que esse bandido fique atrás das grades 'pro' resto da vida dele".

Com base no que foi exposto, portanto, os gráficos adiante dispostos possuem relação com os crimes mais mencionados pelo programa. Desse modo, a elaboração dos mesmos ocorreu através da observação das manchetes divulgadas e comentadas pelos apresentadores do programa, com o intuito de identificar quais são os crimes que possuem maior repercussão penal-punitiva naquele contexto observado. $O$ que rapidamente se percebe é que os crimes sangrentos, como o homicídio, tanto estatisticamente quanto discursivamente, ganham certa notoriedade, como se tivessem o poder de ascender à condição de atração principal, concorrendo com crimes contra o patrimônio, sobretudo aqueles em que há utilização de arma de fogo, e os crimes sexuais, em especial o estupro, senão vejamos:

\section{Gráfico 1 - Dia 5/2/2020 com total de 14 casos}

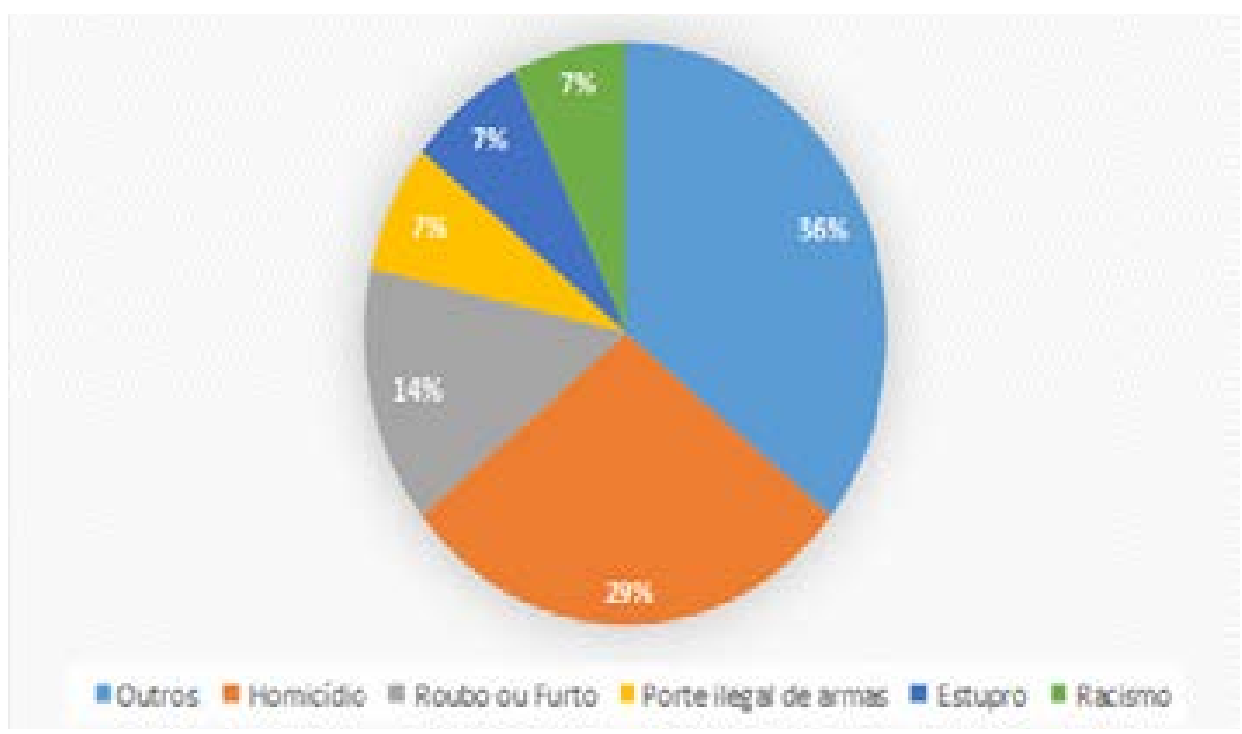

Fonte: Elaborado pelo autor (2020)

9 O vídeo remanescente mais completo deste programa encontra-se no Youtube com 40 minutos. 
Gráfico 2 - Dia 10/2/2020 com total de 11 casos

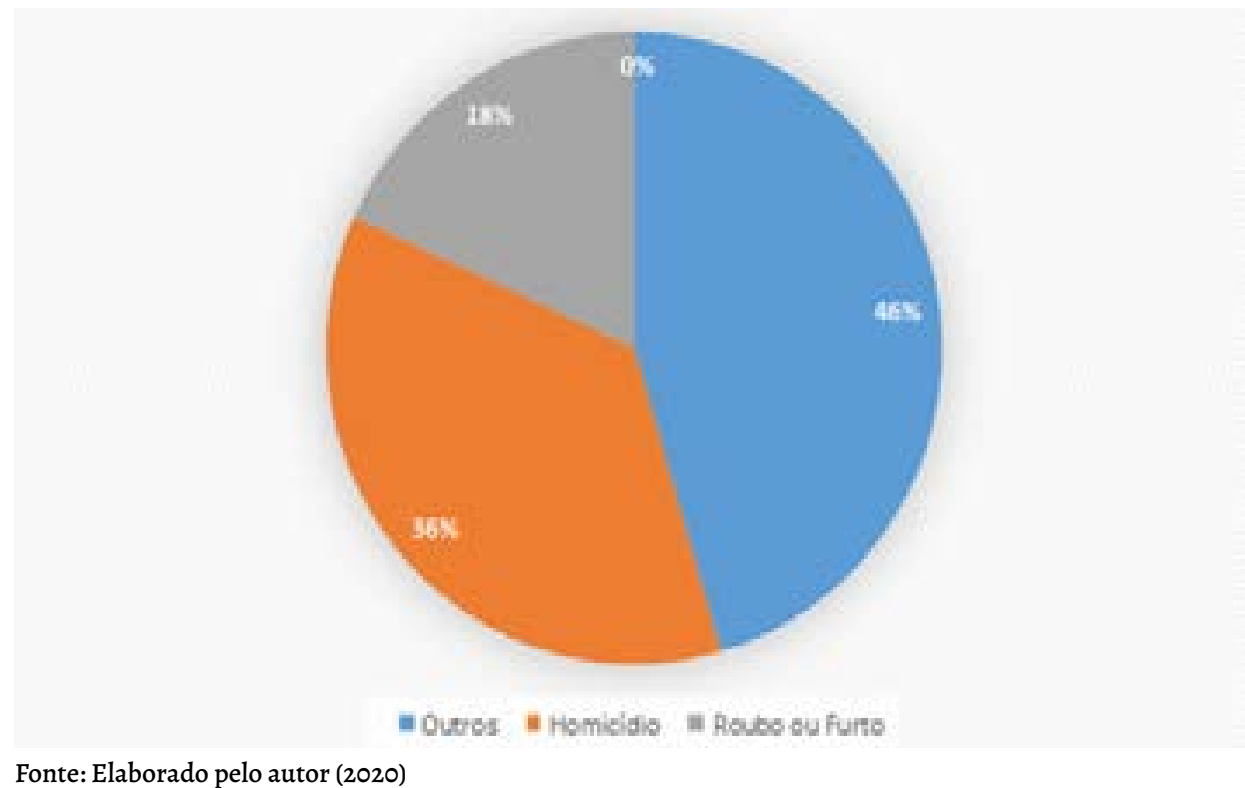

Fonte: Elaborado pelo autor (2020)

\section{Gráfico 3 - Dia 17/2/2020 com total de 16 casos}

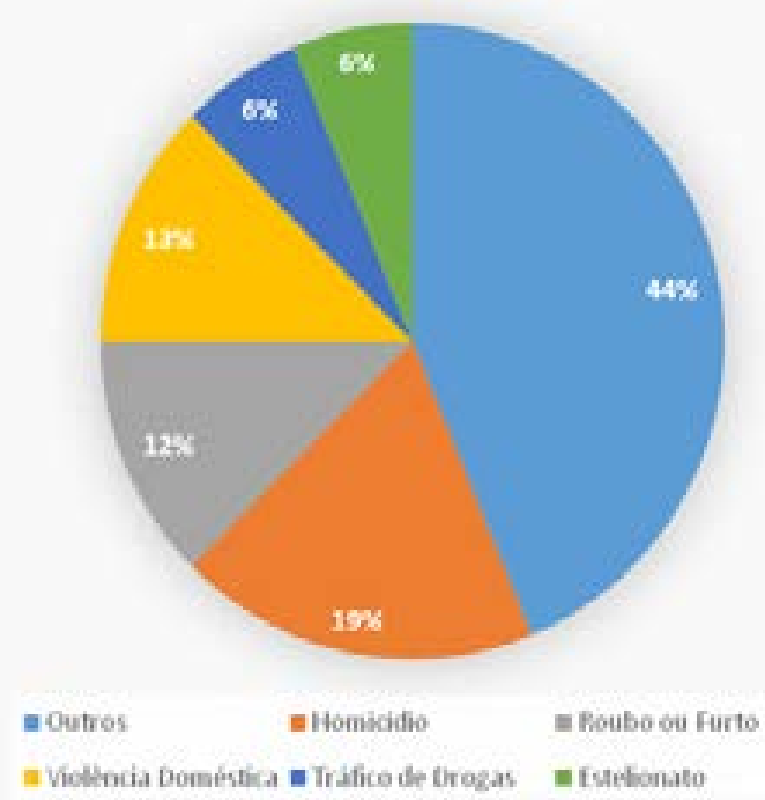

Fonte: Elaborado pelo autor (2020) 
Gráfico 4 - Dia 24/2/2020 com total de 11 casos

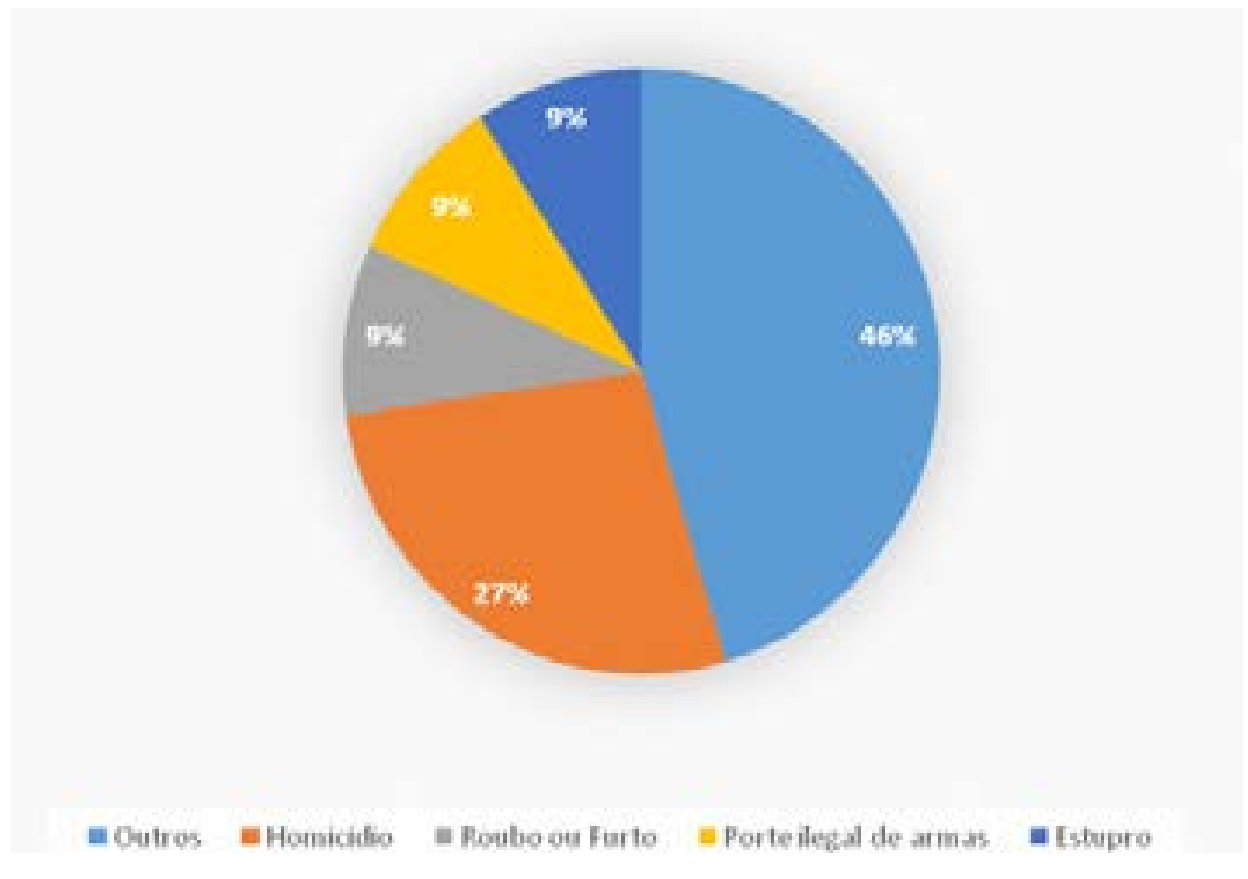

Fonte: Elaborado pelo autor (2020)

Gráfico 5 - Média dos crimes tipificados pelo programa nos 4 dias de observação com total de 52 casos noticiados

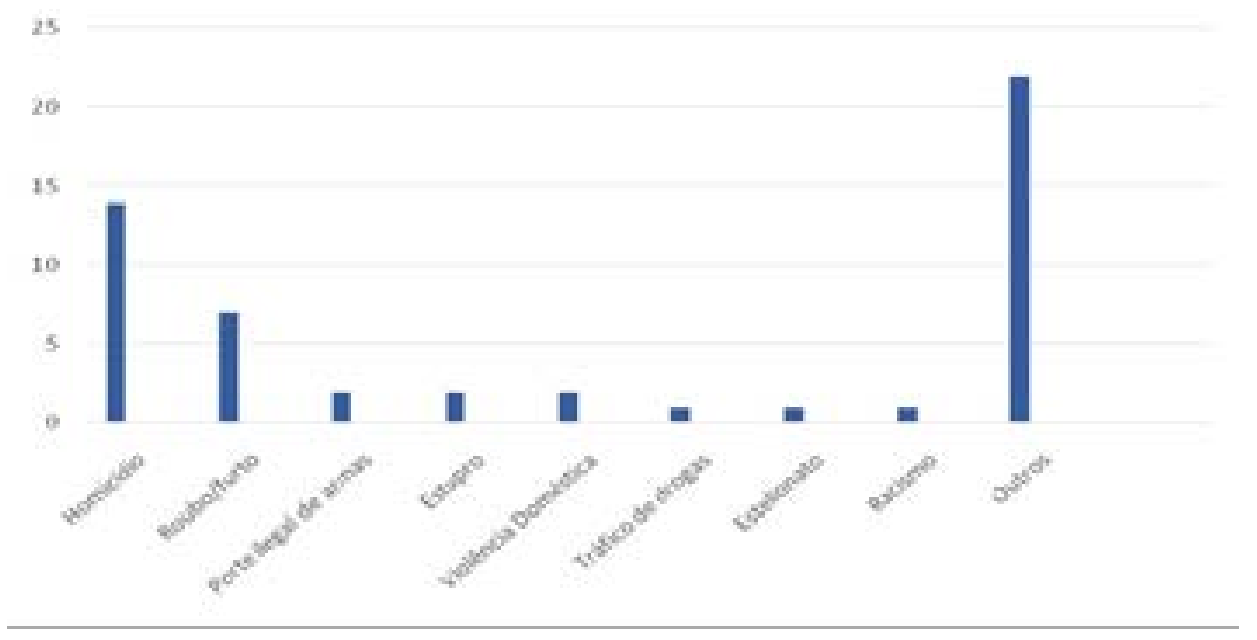

Fonte: Elaborado pelo autor (2020)

Perceba-se, portanto, que, embora a presença de crimes contra a dignidade sexual (como o estupro - no art. 213 do Código Penal) e contra o patrimônio (como o roubo - no art. 157 do Código Penal) seja uma constante no cotidiano do 
programa enfocado, há, como se percebe rapidamente, uma certa prevalência do crime de homicídio no noticiário, justamente por ser o extraordinário, o crime mais impactante, aquele que põe fim à vida, o que chama mais a atenção das pessoas, também potenciais vítimas, despertando a curiosidade não apenas sobre a identidade daquela pessoa assassinada, mas em especial sobre o modus operandi da pessoa apontada como a assassina.

É nesse cenário televisivo em que, mais do que propriamente informar, busca-se atrair a atenção do público, que em diversas outras situações encaradas como criminosas, por vezes classificadas como "outros" nos gráficos (como problemas no trânsito, por exemplo), acabam sendo utilizadas, junto com as propagandas de todo tipo exibidas entre uma manchete e outra, para preencher o tempo do programa observado, mas tudo claramente focado na tentativa de fazer com que as pessoas não mudem de canal.

\section{UM TELEJORNALISMO POLICIAL}

Diante dos dados expostos anteriormente, percebe-se o quanto o programa se torna um verdadeiro combatente, uma espécie de canhão direcionado aos alvos minuciosamente selecionados pela descarada justificativa que permeia a ideia de política criminal brasileira, do crime, um perseguidor de delinquentes, buscando legitimar atuações policiais com maior rigor a fim de diminuir a criminalidade. Com isso, resta evidente e notório como o apresentador fala com visível alegria ao mencionar que algum delinquente morreu, como demonstrado no primeiro caso do primeiro dia. Outrossim, observa-se também como a posição geográfica do apresentador é estratégica enquanto apresenta o programa, sempre em pé, possibilitando movimentos e gestos que possam torná-lo mais próximo ao público, bem como a intenção de dialogar com a plateia ao tempo em que constrói uma narrativa durante a transmissão das imagens do delito.

Nota-se, no segundo caso citado do primeiro dia relatado, a insistência do repórter para que o policial dê depoimentos que possam acusar a pessoa e macular a sua imagem, atribuindo-lhe o sentido mesmo de bode expiatório. Além disso, ao final da matéria, o apresentador em coerência com a atuação do repórter, reafirma a segregação social que deve existir, apelando às emoções dos telespectadores ao mencionar seu filho ou sua filh a com o fim de intensificar a cultura do medo.

Neste viés, ressalta-se a estigmatização constantemente apresentada no programa, demonstrada inclusive durante a segunda reportagem do primeiro dia, em que o repórter se refere à pessoa como criancinha do mal. Ou seja, 
além de todo um interrogatório com o objetivo de culpabilizar o investigado, o repórter ainda o estigmatiza para assim parecer cumprir uma espécie de anseio social (qual seja: a busca pela justiça ou pelo fim da impunidade), travestindo-se na figura do herói (não é por acaso que o super-homem dos quadrinhos se disfarce de jornalista) que está ali combatendo a criminalidade, exercendo seu papel de (des)informar. Na realidade, afigura-se apenas como instrumento mantenedor do status quo punitivo estatal.

Em consonância, vê-se como a estigmatização mencionada persegue o sujeito encarado como delinquente durante toda a sua vida, pois uma vez que ele tenha cometido um crime e sido preso, mesmo que já tenha cumprido sua pena, as pessoas o condenam eternamente como um malfeitor, como é o caso da última reportagem exibida do primeiro dia. Da mesma forma, cria um eles por semelhança, como menciona Zaffaroni (2012, p. 307):

Para tanto, a criminologia midiática joga com imagens, selecionando as que mostram os poucos estereotipados que delinquem, $\mathrm{e}$ em seguida os que não cometeram crimes ou que só incorreram em infrações menores, mas são parecidos. Não é necessário verbalizar para comunicar que a qualquer momento os parecidos farão o mesmo que o criminoso.

Paralelamente, fala-se de uma condição de comunicação que é imposta ao indivíduo como forma de censura, sobretudo ao que se refere ao tempo que é disponibilizado para o discurso, impossibilitando espaços de diálogo, na linha de Bourdieu (1997, p. 19).

A televisão, portanto, cria uma narrativa de dramatização em que "os jornalistas têm 'óculos" especiais a partir dos quais vêem certas coisas e não outras; e vêem de certa maneira as coisas que vêem. Eles operam uma seleção e uma construção do que é selecionado". (BOURDIEU, 1997, p. 25)

De certo, um dos pontos bem trabalhados no livro Sobre a televisão de Bourdieu é o que ele traz sobre os chamados fast-thinkers, em que liga a necessidade de urgência em passar a notícia com a impossibilidade de formar um pensamento racional. Ou seja, nem o próprio apresentador consegue escapar desse fenômeno, contudo ele precisa dar uma resposta. Com isso, utiliza-se de ideias feitas que, segundo explicação de Bourdieu (1997, p. 40) “as 'ideias feitas' que fala Flaubert são ideias aceitas por todo mundo, banais, convencionais, comuns; mas são também ideias que, quando as aceitamos, já estão aceitas, de sorte que o problema da recepção não se coloca". 
Com isso, pode-se perceber que a maior incidência de casos relatados são os de homicídios, num total de 14 (quatorze) casos em 4 (quatro) dias de telejornal, preferencialmente os de caráter doloso para ter uma maior sensibilização para os telespectadores, ficando os casos de roubo ou furto em segundo lugar com 7 (sete) casos.

Desta feita, segue-se uma linha de padronização do que deve ser relatado aos programas, escolhidos aqueles que podem instigar maior ódio e repressão por parte dos receptores das notícias, como crimes mais sanguinários e crimes patrimoniais. Ademais, frisa-se a importância dessas escolhas temáticas, pois é totalmente intencional para criação do senso comum punitivo, sempre reiterando a má personalidade da pessoa eventualmente investigada pelo sistema formal de controle e a ausência de devida punição por parte do Estado.

Deste modo, vê-se como o programa que se torna policial tem como fundamento a manipulação da alegada racionalidade socialmente difundida a partir das opiniões que emite diariamente, transmitindo discursos aparentemente verdadeiros, que a pretexto de realizar justiça, ao contrário, geram animosidade, disseminam medo e discursos de ódio para com a população do eles, ansiando-se por um direito penal mais repressivo que tem endereço certo.

\section{EFEITOS DO POPULISMO PUNITIVO}

Elena Larrauri (2006), uma das criminólogas que mais discute a questão do populismo punitivo, traz que esse movimento começou a partir da transição entre um modelo embasado na ressocialização para um modelo que persegue a incapacitação dos delinquentes.

Sobre seu conceito:

$\mathrm{Na}$ opinião deste último autor, [Bottoms], populismo punitivo se refere à quando o uso do direito penal por três governantes aparece guiado por três pressupostos: que maiores penas podem reduzir o crime; que as penas ajudam a reforçar o consenso moral existente na sociedade; e que há lucro eleitoral, que é produto deste uso. (LARRAURI, 2006, p. 15, tradução nossa) ${ }^{10}$

Isto posto, tem-se que o populismo punitivo ganha maiores adeptos após a Segunda Guerra Mundial, quando não havia mais um controle eficiente

10 En opinión de este último autor, populismo punitivo se refiere a cuando el uso del derecho penal por los gobernantes aparece guiado por três asunciones: que mayores penas pueden reducir el delito; que las penas ayudan a reforzarel consenso moral existente em la sociedad; y que hay unas ganancias electoral es producto de este uso (texto original). (LARRAURI, 2006, p. 15) 
de delitos, adotando-se uma teoria de cultura de controle, discutida, por exemplo, em Garland (2001 apud LARRAURI, 2006, p. 15), passando o Estado a governar não propriamente contra o crime, mas através dele (governing through crime), na esteira de Simon (1997 apud LARRAURI, 2006, p. 15).

Nessa movimentação despontada no início da era moderna sobre a lida com o crime se destaca o fim de uma era marcadamente colonial de grandes desigualdades territoriais, tendo como fruto um forte sentimento de diferença, dificuldade e racismo, acrescentando-se a um sentimento também de insegurança de uma sociedade que passa a enfrentar novos (e democratizados) riscos. Ou seja, ao se submeterem aos intensos processos de hostilidade as pessoas se tornam mais conscientes e mais indispostas a tolerar algo que leve ao retorno do alegado desequilíbrio social (LARRAURI, 2006, p. 16).

Por conseguinte, esta cultura do controle foi fortemente utilizada como meio de discurso nas campanhas eleitorais, ficando conhecida como uma estratégia aliada à emergencialidade pela qual a sociedade passava. Em vista disso, Sozzo (2009, p. 42, grifo do autor) aduz que:

\begin{abstract}
A insegurança urbana foi se transformando em um objeto de troca política, uma "mercadoria política", através da qual se busca a produção de consenso político e no limite, eleitoral. Se trata de um novo tipo de "politização", de uma matéria já reconhecida dos mais variados pontos de vista como "política". Talvez possa ser pensado como uma "eleitoralização".

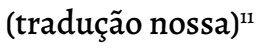

Deste modo, a severidade do castigo se transforma, de forma progressiva, ao que Sozzo (2009, p. 43) chama de "receita fundamental" para as estratégias de controle do delito, pleiteando um endurecimento da política criminal e penitenciária, tanto no plano dos discursos como também na prática.

Para além disto, Sozzo (2009, p. 43) critica a ideia exposta acima de Garland (2005) ao se valer de uma "criminologia do outro" para a construção discursiva de uma representação do delinquente, utilizando-se de estereótipos e imagens, quando deveria estar fundamentando sua análise em uma meticulosa investigação científica. Outrossim:

11 La inseguridad urbana se fue transformando asíen un objeto de intercambio político, una "mercancía política", a través de la cual se busca bala producción de consenso político y enel límite, electoral. Se trata de um nuevo tipo de "politización" - de una matéria ya reconocida desde los mas variados puntos de vista como "política". Tal vez se podría pensar mas bien como una "electoralización". (SOZZO, 2009, p. 42) 
Para Pratt (2007, p. 53 apud GLOECKNER; RAMOS, 2017, p. 257), a dimensão populista do fenômeno punitivo se expressa pelo fato de que há, nas sociedades modernas, um descontentamento popular generalizado relativamente ao funcionamento do sistema de justiça criminal; tal descontentamento traduzir-se-á - a exemplo do que ocorre no cenário nacional - numa série de discursos que, fazendo confluir os significantes impunidade, medo e violência, tem reivindicado a formação de uma fronteira interna no espaço social que separa, de um lado o povo, constituído, sobretudo, pelas vítimas da violência urbana, e, de outro, uma identidade política marginalizada que, de acordo com a crença que se encontra hoje difundida, tende a se beneficiar, direta ou indiretamente, com a complacência de um direito penal garantista. (grifo do autor)

Neste diapasão, o tripé impunidade, medo e violência é altamente utilizado pelos discursos midiáticos, objeto da pesquisa, como forma de política criminal cujo objetivo é incitar a segregação e consequente perseguição do eles para com os cidadãos de bem, se valendo de um falso direito penal garantista.

Gloeckner e Ramos (2017) citam a patologia de acusação e a patologia da representação, conforme o magistrado francês Salas (2010, p. 14 apud GLOECKNER; RAMOS, 2017, p. 260), como explicação da funcionalidade (ou sua falta) do discurso populista ao propor a ressignificação do ato de punir. Deste modo,

A negatividade inerente ao ato é obnubilada, em grande parte, por uma nova conotação prenhe de positividade: a punição dá-se não tanto em prejuízo dos criminosos, mas sim em favor das vítimas. Assim, ressignificado, o poder de punir é radicalizado, a sociedade, carente de segurança, passa a exigir mais acusações, mais julgamentos e mais condenações. Frente a esse contexto, os legisladores passam a operar com o intuito de superar aquilo que representa a segunda patologia identificada pelo autor: a crise de representatividade política, que, agravada, passa a representar a própria crise de legitimidade da forma-partido e do parlamento, enquanto instituição. (GLOECKNER; RAMOS, 2017, p. 260)

Porquanto, fica aqui demonstrado que o Estado passa a funcionar em consonância com as pulsões sociais (FREUD, 2013) colocadas em permanente estado de bombardeio midiático, permitindo a sensação de que o povo está à frente das decisões com relação a devida punição do infrator.

Não obstante, percebe-se que o populismo punitivo veio ganhando força no Brasil com base nos discursos políticos e, consequentemente, midiáticos, a fim de produzir uma resposta frente as pulsões de emergencialidade da crescente criminalidade, gerando uma forte tendência de punição mais severa. 


\section{UM DIREITO PENAL DO INIMIGO}

Conforme discussão ao longo do presente estudo, tem-se como uma das formas de legitimação do senso comum punitivo os preceitos do direito penal do inimigo. Por isso, hodiernamente, os ensinamentos do direito penal do inimigo introduzidos por Jakobs, no final do século XX, de que, em resumo, devem existir para o direito penal os cidadãos e os não-cidadãos, parece-nos ser tão atual quanto à época.

Posto isso, a diferença entre o direito penal comum e o direito penal do inimigo, é que enquanto um se manifesta pela contradição, o outro visa a eliminação de um perigo, personalizado em um indivíduo transgressor assim estigmatizado. (JAKOBS, 2007)

Por outro lado, o positivismo de Garofalo (1851-1934) não é muito diferente dos ensinamentos de Jakobs (2007), como nos adverte Zaffaroni (2007, p. 92, grifo do autor):

As expressões mais grosseiras desta teorização da periculosidade e da pretensão da individualização ôntica do inimigo pertencem a Rafael Garofalo, para quem a ciência penal teria por objeto a defesa contra 'os inimigos naturais da sociedade' e a indulgência dos magistrados não seria mais que "o triunfo da lógica conseguido às expensas da segurança e da moralidade sociais".

Porquanto, esta experiência teria como base a imposição de penas limitadas aos iguais e penas ilimitadas aos diferentes ou inimigos.

Ademais:

Imaginar que é possível incrementar o poder punitivo só com relação a inimigos não identificáveis $a b$ initio é uma ingenuidade, para não dizer uma grave falta de senso. O que se discutirá, nesse caso, será se é possível reduzir as garantias de toda a população frente ao aparato repressivo e impor-lhe os controles, limitações e eventuais penalidades indevidas como consequência, em homenagem a uma pretensa e mais do que duvidosa eficácia da empresa humanitária do poder punitivo que declara perseguir apenas a neutralização do risco de emergência do momento. (ZAFFARONI, 2007, p. 118, grifo do autor)

Com isso, não resta dúvidas que o poder de individualização de agentes criminosos tem como principal questão a política, em detrimento dos direitos e garantias dos cidadãos em prol de um direito penal do inimigo, indo contra o Estado constitucional de direito, cujo objetivo é a perseguição e eliminação do eles estigmatizados. Portanto, para isso, contextualiza Zaffaroni (2007, p. 120) 
que o problema da inviabilidade empírica da política criminal desse tipo de direito penal (o do inimigo), ao divulgar a realidade prática de que, apesar da tentativa de separação dos dois direitos penais (cidadão vs inimigo), não há como evitar afetação mútua.

Assim, tais políticas criminais de viés autoritário visam uma alegada emergencialidade, o eficientismo e o simbolismo, sendo prudente questionar em que medida existe essa emergência, pois será que seria capaz de passar por cima dos direitos e garantias dos indivíduos, como prega o eficientismo? A concepção de parte do ideário popular atribuída à Maquiavel de que os fins justificam os meios nunca fez tanto sentido nos dias de hoje. Além disso, não se pode esquecer do simbolismo, no sentido de que a política só serve para aplacar os anseios da sociedade, não possuindo, de fato, eficácia.

\section{CONSIDERAÇÕES FINAIS}

A criminologia midiática conduz a noções construídas com base em políticas criminais que primem pelo caráter de emergência, eficientismo e consequente simbolismo, formando o senso comum punitivo. Esse que, por sua vez, vale-se principalmente do discurso midiático, representado pela imagem do apresentador, aquele que é o condutor da notícia e quem tem maior impacto na sua transmissão, pois como fora demonstrado, é através da figura do apresentador que o telejornal passa a credibilidade e a confiança de que tanto precisa, utilizando-se de termos e gestos para obter uma maior aproximação com o telespectador.

Por isso mesmo, buscou-se investigar e explicar essa política criminal de cunho populista (com forte poder de atração da atenção das pessoas), que tanto reforça o senso comum repressivo, com o fim de romper com a estigmatização da pessoa exposta e com a ideia de emergencialidade do uso severo do sistema criminal. Restou, portanto, demonstrado a partir dos dados apresentados que esta política criminal está tão enraizada na dinâmica jornalística, nos programas mais populares, em especial no programa enfocado, que se preciso for, direitos e garantias individuais cederão em favor de um alegado senso de justiça.

Conquanto, ao se aprofundar a questão enfocada, observa-se a aberração que tais discursos disseminam, mas que parecem se tornar reais e legítimos na medida em que parte da sociedade (convém não generalizar, portanto), apressadamente, não busca estimular o senso crítico com o contato com outras fontes, sobretudo porque geralmente adere à lei do menor esforço ao exercitar o cérebro, o que essa mídia de massa potencializa.

Destarte, enquanto boa parte das pessoas está ocupada pensando em como combater essa criminalidade de rua, seja punindo mais severamente, seja 
cobrando a criação ou o endurecimento de leis ou mesmo induzindo a segregação de pessoas já marginalizadas socialmente, os grandes empresários estão (por vezes até literalmente) se divertindo às custas do que produz a sociedade. Em razão disso, incrementam a política de extermínio de vidas e de reputações, tudo com o fim de parecer alguém (sobretudo no caso de políticos) que está antenado com o sentimento do povo, para quem (muitos deles dizem que) trabalham.

Não se pode esquecer do papel que o telespectador exerce nesse processo discursivo de circularidade de uma mentalidade autoritária, uma vez que é este quem dá audiência, para quem esse tipo produto é entregue, devendo-lhe, portanto, em uma democracia, pesar a responsabilidade do controle social informal, o que tende a ser deficitário na medida em que nos deparamos com uma população com um grau menor de politização e/ou de escolaridade. Logo, uma tentativa de amainar o problema enfocado não passa exatamente por iniciativas que espartilhem a possibilidade de exibição de tais programas (longe disso), mas por um esforço no sentido da criação e da manutenção de cada vez mais espaços de conscientização das pessoas da necessidade de se preservar direitos e garantias fundamentais envolvidos nesse processo, dotando-as da capacidade de pensar criticamente a respeito.

Por fim, mostrou-se como evidente a postura da mídia policial enfocada ao revelar o tripé impunidade, medo e violência que estimula a vitimização e a cultura do medo, seguindo a corrente da política criminal autoritária, que visa a propagação do senso comum punitivo.

\section{REFERÊNCIAS}

BRASIL. Lei de 16 de dezembro de 1830. Institui o Código Criminal do Império do Brazil. Brasília, DF: Presidência da República, 1830. Disponível em: http://www.planalto.gov. br/ccivil_03/leis/lim/lim-16-12-1830.htm. Acesso em: 7 mar. 2020.

BOURDIEU, P. Sobre a televisão. Tradução de Maria Lucia Machado. Rio de Janeiro: Jorge Zahar, 1997.

FREUD, S. Psicologia das massas e análise do eu. Porto Alegre: L\&PM, 2013.

GARLAND, D. La cultura del control: crimen y orden social em la sociedade contemporânea. Tradução de Máximo Sozzo. Barcelona: Gedisa, 2005.

GIRARD, R. A violência e o sagrado. Tradução de Martha Conceição Gambini. São Paulo: Editora Unesp, 1990.

GLOECKNER. R. J.; RAMOS, M. B. Os sentidos do populismo penal: uma análise para além da condenação ética. Delictae: Revista de Estudos Interdisciplinares sobre o Delito, Belo Hori-zonte, v. 2, n. 3, p. 248-297, 2017. 
JAKOBS, G. Direito penal do inimigo: noções e críticas. Tradução de André Luís Callegari e Nereu José Giacomolli. 2. ed. Porto Alegre: Livraria do advogado, 2007.

LARRAURI, E. Populismo punitivo y como resistirlo. Juezas y Jueces para la democracia: informacion y debate. Madri, n. 55, p. 15-22, 2006.

LIMA, T. S. Onde estão os mortos?: silenciamento, discursos e os sentidos midiáticos da paci-ficação do Complexo do Alemão. 2015. 280 f. Dissertação (Programa de Pós-Graduação em Mídia e Cotidiano) - Instituto de Arte e Comunicação Social, Universidade Federal de Flu-minense, Niterói, 2015.

MAGALHÃES, T. TV Ponta Verde mostra aos parceiros crescimento na audiência e Tribuna destaca parceria. Tribuna Hoje, Maceió, 2019. Disponível em: https:// tribunahoje.com/noticias/cidades/2019/06/14/tv-ponta-verde-mostra-aos-parceiroscrescimento-na-audiencia-e-tribuna-destaca-parceria/. Acesso em: 1 out. 2020.

NATALINO, M. A. C. O discurso do telejornalismo de referência: criminalidade violenta e controle punitivo. São Paulo: Método, 2007.

PLANTÃO Alagoas. Maceió: SBT, 5 fev. 2020a. 1 vídeo (86min). Publicado pelo canal TV Ponta Verde SBT. Disponível em: https://www.youtube.com/watch?v=Wdi1PmRQJdo. Acesso em: 15 mar. 2020.

PLANTÃO Alagoas. Maceió: SBT, 10 fev. 2020b. 1 vídeo (38 min). Publicado pelo canal TV Ponta Verde SBT. Disponível em: https://www.youtube.com/ watch?v=OkHAvwlgyE4. Acesso em: 16 mar. 2020.

PLANTÃo Alagoas. Maceió: SBT, 17 fev. 2020c. 1 vídeo (88 min). Publicado pelo canal TV Ponta Verde SBT. Disponível em: https://www.youtube.com/ watch?v=MJOFQXg5iHk\&t=306s. Acesso em: 16 mar. 2020.

PLANTÃO Alagoas. Maceió: SBT, 24 fev. 2020 d. 1 vídeo (40 min). Publicado pelo canal TV Ponta Verde SBT. Disponível em: https://www.youtube.com/watch?v=-y_VoKEf_wE. Acesso em: 17 mar. 2020.

SANTOS, H. L. R. As palavras e as penas: comentários sobre o discurso criminal da barbárie. Revista Eletrônica da Faculdade de Direito da Universidade Federal de Pelotas, Pelotas, v. 2, n. 2, p. 20-28, 2016.

SOZZO, M. Sistema penal e violência. Revista Eletrônica da Faculdade de Direito, Porto Alegre, v. 1, n. 1, p. 33-65, 2009.

ZAFFARONI, E. R. A palavra dos mortos: conferências de criminologia cautelar. Tradução de Sérgio Lamarão. São Paulo: Saraiva, 2012.

ZAFFARONI, E. R. A questão criminal. Tradução de Sérgio Lamarão. Rio de Janeiro: Revan, 2013.

ZAFFARONI, E. R. O inimigo no direito penal. Tradução de Sérgio Lamarão. 2. ed. Rio de Janeiro: Revan, 2007. 